\title{
Properties of a Mutant of Pseudomonas aeruginosa Affected in Aerobic Growth
}

\author{
By J. VAN HARTINGSVELDT AND A. H. STOUTHAMER \\ Microbiology Department, Biological Laboratory, Free University, \\ De Boelelaan 1087, Amsterdam, The Netherlands
}

(Received 20 December 1973; revised 2I February 1974)

SUMMARY

\begin{abstract}
A mutant of Pseudomonas aeruginosa affected in aerobic growth (aer) was partially characterized. When shifted from anaerobic to aerobic conditions mutant bacteria continued growth. During this aerobic growth after the shift the mutant bacteria differed from the wild type in some respects. First, the concentration of intracellular haem decreased gradually, whereas coproporphyrin was released into the culture fluid. Apparently haem synthesis is blocked under aerobic conditions, so oxygen uptake by the mutant culture did not increase as much as by the wild type after a shift. Second, the anaerobic nitrate-respiratory system of the mutant exhibited an altered sensitivity to oxygen after a shift to aerobiosis. Nitrate and nitrite reduction were not inhibited and nitrite reductase synthesis was not repressed by oxygen. $\mathrm{P} / \mathrm{O}$ values determined in intact bacteria showed that respiration with oxygen was still coupled to ATP formation in the mutant.
\end{abstract}

\section{INTRODUCTION}

Pseudomonas aeruginosa can grow anaerobically only by anaerobic respiration, in which nitrate is used as terminal electron acceptor (Yamanaka, Ota \& Okunuki, 196I). Van Hartingsveldt \& Stouthamer (1973) isolated a mutant (aer) affected in aerobic growth and which can grow only under anaerobic conditions, or at low oxygen tensions, in the presence of nitrate. After anaerobic cultivation no differences in respiration rate, cytochrome spectra, or nitrate and nitrite reduction were observed between aer mutant and wild-type bacteria. However, differences might be expected only when mutant and wild type are incubated aerobically. We report the effects of a shift from anaerobic to aerobic conditions in growing cultures of mutant and wild-type bacteria.

\section{METHODS}

Bacterial strains. Wild-type strain s838 and mutant strain SI 276 of Pseudomonas aeruginosa were used (van Hartingsveldt, Marinus \& Stouthamer, 197I; van Hartingsveldt \& Stouthamer, I973).

Media and general culture procedures. Bacteria were grown in a Microferm laboratory fermentor (New Brunswick Scientific Co.) in brain-heart infusion (Oxoid) supplemented with $0.4 \%$ glucose $(\mathrm{BHI})$. Aerobic growth was obtained by stirring at $400 \mathrm{rev} . / \mathrm{min}$ with sparging of air at $21 / \mathrm{min} / 1$ medium. Anaerobic growth was achieved by adding $0.5 \%(\mathrm{w} / \mathrm{v})$ $\mathrm{KNO}_{3}$ to the medium and sparging with pure nitrogen. Growth at fixed dissolved oxygen concentrations was carried out by means of a dissolved oxygen controller (New Brunswick Scientific Co., Model DO-60). Growth was followed by measuring the extinction at $660 \mathrm{~nm}\left(E_{660}\right)$. 
Shift experiments. At an extinction of about 0.25 , bacteria growing anaerobically were shifted to aerobic conditions and cultured to the stationary phase. To follow aerobic growth after a shift in the absence of nitrate or nitrite, a smaller amount of nitrate $(0.02 \%$, $\mathrm{w} / \mathrm{v}$, instead of $0.5 \% \mathrm{KNO}_{3}$ ) was added to the medium in some experiments, so that nitrate and nitrite were already spent at the moment of the shift.

Oxygen consumption. The oxygen consumption during growth was measured by means of a Servomex oxygen analyser OA I 84 (Servomex Controls Ltd, Crowborough, Sussex).

Enzyme assays. In cell-free extracts nitrate reductase was determined by measuring the production of nitrite from nitrate with reduced benzylviologen as hydrogen donor in open tubes (van 'T Riet, Stouthamer \& Planta, 1968). Specific activity is expressed as $\mu \mathrm{mol}$ nitrite produced $/ \mathrm{min} / \mathrm{mg}$ protein, total activity as $\mu \mathrm{mol}$ nitrite produced $/ \mathrm{min} / 100 \mathrm{ml} \mathrm{cul}$ ture. Nitrite reductase activity was measured anaerobically in resting bacteria as described by Pichinoty, Bigliardi-Rouvier \& Rimassa (I969). Specific activity is expressed as $\mu \mathrm{mol}$ nitrite converted/min/100 $\mathrm{ml}$ culture. Protein was determined according to Lowry, Rosebrough, Farr \& Randall (195I).

Determination of haem, coproporphyrin, nitrite and nitrate. Intracellular haem was determined as pyridine-haemochromogen according to the procedure of Wittenberg \& Sistrom (I97I). The amount was calculated from $\epsilon(550-530 \mathrm{~nm})=22 \cdot \mathrm{I} 1 / \mathrm{mmol} / \mathrm{cm}$. Coproporphyrin was extracted from the culture fluid and determined as described by Falk (1964). The amount was calculated from $\epsilon(40 \mathrm{I}-430 \mathrm{~nm})=489 \mathrm{l} / \mathrm{mol} / \mathrm{cm}$.

Nitrate was measured with a nitrate ion electrode, Model 92-07 (Orion Research Inc., Cambridge, Massachusetts, U.S.A.). Concentrations were calculated from a standard curve. Nitrite was measured as described by van 'T Riet et al. (1968).

Oxidative phosphorylation. Stationary phase bacteria were washed twice with cold $25 \mathrm{~mm}$-potassium phosphate buffer containing $0.4 \mathrm{M}-\mathrm{MgSO}_{4}(\mathrm{pH} 7 \cdot 2)$ and resuspended in this buffer to a concentration of 40 to $80 \mathrm{mg}$ dry wt/ml. Oxidative phosphorylation in these bacteria was determined as described by van der Beek \& Stouthamer (1973).

Growth yields. Bacteria were grown in the defined medium of MacKechnie \& Dawes (I969), with sodium succinate as sole carbon and energy source. Molar growth yields were calculated from the dry weight of bacteria and the consumption of succinate, both determined several times during the exponertial phase of growth. Dry weights were determined by filtration (de Vries \& Stouthamer, 1968). Succinate was assayed by gas-liquid chromatography (de Vries, van Wijck-Kapteijn \& Stouthamer, 1972). It was measured as the methyl derivative prepared as described by Cato et al. (1970).

\section{RESULTS}

\section{Shift experiments}

Growth. The aer mutant bacteria were able to continue growth after a shift from anaerobic to aerobic conditions (Fig. I). Even in the absence of nitrate or nitrite growth did not stop after the shift. The growth rate did not alter in the mutant, whereas it increased in the wild type. The maximum extinction of the culture was lower for the mutant than for the wild type.

Nitrate and nitrite reductase activities. Immediately after a shift from anaerobic to aerobic conditions the total nitrate reductase activity in the wild type decreased. In the aer mutant it hardly changed for about $30 \mathrm{~min}$ and then decreased to the same level as in the wild type (Fig. 2). However, the total nitrite reductase activity increased in the mutant and decreased in the wild type (Fig. 2). Specific activities of nitrate and nitrite reductase decreased both in the aer mutant and the wild type after the shift. 


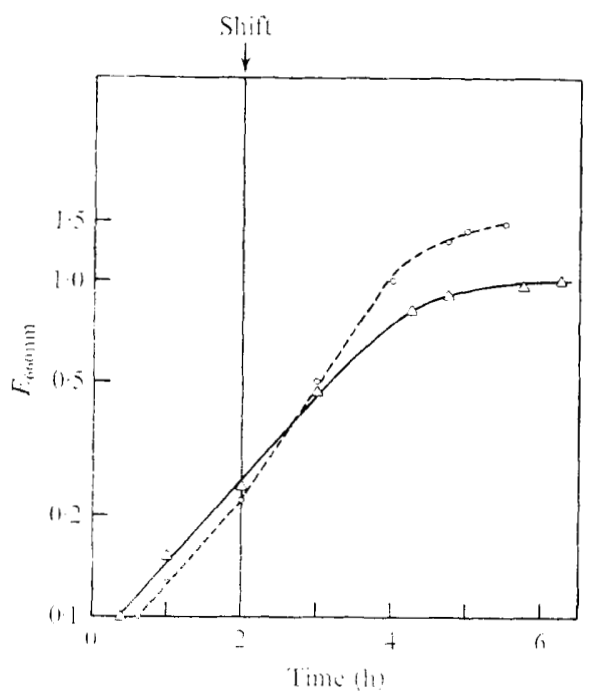

Fig. I

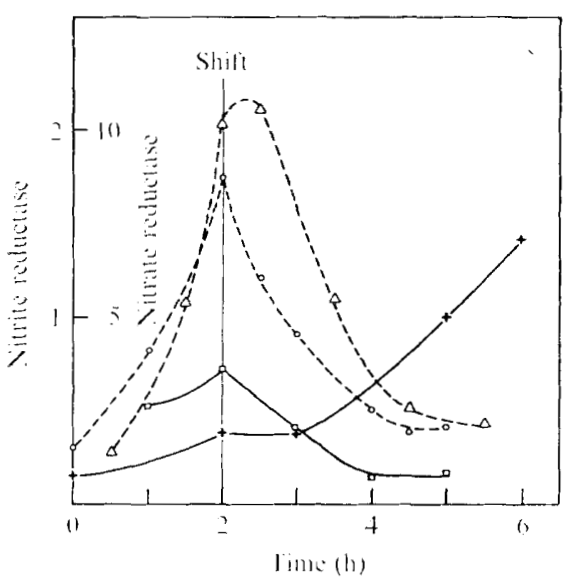

Fig. 2

Fig. I. Growth of Pseudomonas aeruginosa s838 wild type and SI 276 aer in BHI with $0.5 \% \mathrm{KNO}_{3}$ before and after a shift from anaerobic to aerobic conditions, given as the extinction at $660 \mathrm{~nm}$. $0, \mathrm{~s}_{3} 8 ;$; s 1276 .

Fig. 2. Total activity of nitrate reductase ( $\mu \mathrm{mol}$ nitrite produced $/ \mathrm{min} / 100 \mathrm{ml}$ culture fluid) and nitrite reductase ( $\mu \mathrm{mol}$ nitrite converted $/ \mathrm{min} / \mathrm{I} / 0 \mathrm{ml}$ culture fluid) in cultures of $P$. aeruginosa s 838 wild type and SI $276 \mathrm{aer}$ before and after a shift from anaerobic to aerobic conditions. Growth conditions as in Fig. I. $\bigcirc$, Nitrate reductase in $s 838 ; \Delta$, nitrate reductase in $s 1276 ; \square$, nitrite reductase in $s 838 ;+$, nitrite reductase in $\$ 1276$.

Nitrate and nitrite concentrations in the culture fluid. The concentrations of nitrate and nitrite in the culture fluids of wild-type and mutant bacteria were measured before and after a shift from anaerobic to aerobic conditions (Fig. 3). In the wild type both nitrate and nitrite reduction stopped within about $30 \mathrm{~min}$ of the shift, whereas they continued in the mutant. Since nitrite accumulated, the rate of nitrate reduction was greater than of nitrite reduction.

Haem and porphyrin determinations. When aer mutant bacteria were shifted from anaerobic to aerobic conditions the pink colour of the bacteria, caused by haem compounds, gradually disappeared. Therefore intracellular haem was determined before and after a shift from anaerobic to aerobic conditions (Fig. 4). The total haem concentration in the mutant culture decreased after the shift, whereas a strong increase was observed in the wild-type culture. Subsequently porphyrin concentrations in the culture fluid were determined (Fig. 5). In the mutant culture considerable amounts of coproporphyrin accumulated under aerobiosis. No protoporphyrin could be detected. The wild type hardly released porphyrins. In the aer mutant a defect in the synthesis of haem under aerobic conditions is probably present.

Mutant bacteria cultured under several dissolved-oxygen tensions in the presence of nitrate also released coproporphyrin into the medium (Table 1). An increase in the oxygen tension increased the accumulation of coproporphyrin in the medium. Only at high dissolved-oxygen tensions was a decrease in the intracellular haem observed.

Haemin added to the growth media $(2 \mu \mathrm{g} / \mathrm{ml})$ did not restore the ability for normal aerobic growth. Probably this compound is not taken up by Pseudomonas aeruginosa.

Respiration rate. Although no differences in respiration rate were found between the aer mutant and the wild type after anaerobiosis (van Hartingsveldt \& Stouthamer, 1973), a 


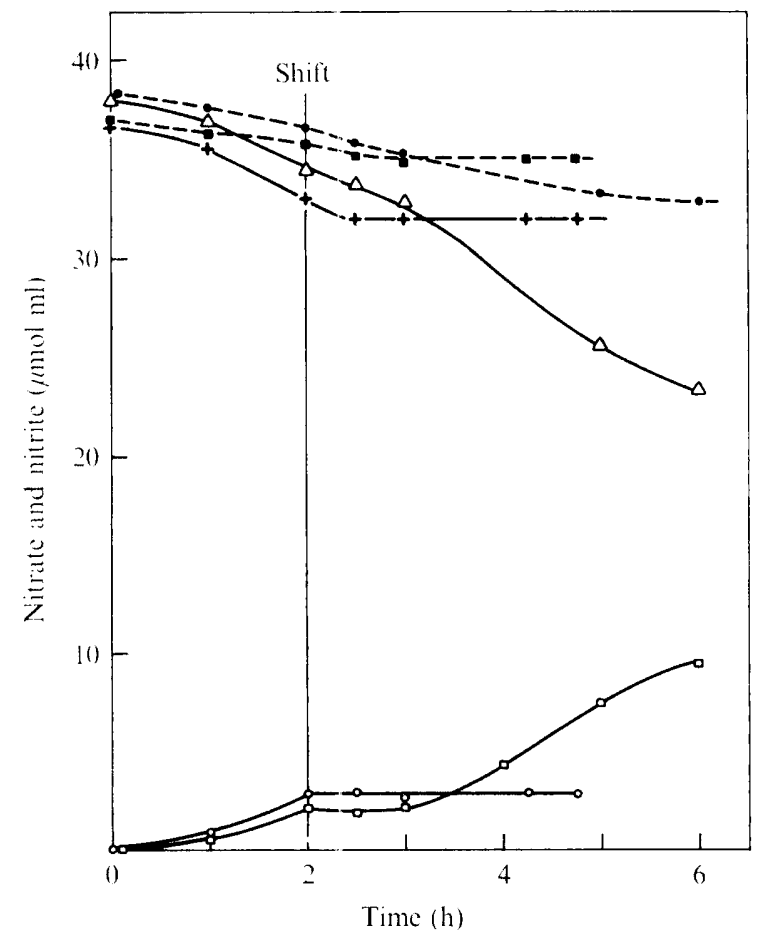

Fig. 3. Concentrations of nitrate, nitrite and nitrate + nitrite in the culture fluid of $P$. aeruginosa s838 wild type and s 1276 aer before and after a shift from anaerobic to aerobic conditions. Growth conditions as in Fig. I. $\bigcirc$, Nitrite concentration for $s 838$; $\square$, nitrite concentration for sI 276; + , nitrate concentration for $s 838 ; \triangle$, nitrate concentration for $s I 276 ; \boldsymbol{a}$, concentration of nitrate + nitrite for $\mathrm{s} 838$; , concentration. of nitrate + nitrite for SI 276 .

difference in oxygen uptake was detected between growing bacteria of both strains after a shift to aerobiosis (Fig. 6). The total oxygen uptake of the wild-type culture increased considerably during growth after the shift, whereas it reached a low level in the mutant culture. Specific oxygen uptake increased in the wild type and decreased in the mutant culture.

Table I. Intracellular haem and coproporphyrin accumulation in the culture fiuid of growing bacteria of the aer mutant strain of $P$. aeruginosa cultured at different dissolved oxygen concentrations in the presence of $\mathrm{KNO}_{3}$, determined at $E_{660 \mathrm{~mm}}$ of $\mathrm{O} \cdot \mathrm{I}$ (start of the experiment) and $0 \cdot 8$.

\begin{tabular}{|c|c|c|c|}
\hline \multirow{2}{*}{$\begin{array}{c}\text { Dissolved oxygen } \\
\left(\mu \mathrm{M}-\mathrm{O}_{2}\right)\end{array}$} & \multicolumn{2}{|c|}{$\begin{array}{c}\text { Haem } \\
(\mathrm{rmol} / \mathrm{mg} \text { protein })\end{array}$} & \multirow{2}{*}{$\overbrace{E_{660}=0.8}^{\begin{array}{c}\text { Coproporphyrin } \\
(\mathrm{nmol} / \mathrm{ml} \text { medium) }\end{array}}$} \\
\hline & $E_{660}=0.1$ & $E_{660}=0.8$ & \\
\hline I 2.5 & 0.68 & 0.25 & 75 \\
\hline 37.5 & 0.76 & 0.20 & I 30 \\
\hline 50 & 0.67 & 0.14 & 260 \\
\hline 150 & 0.79 & 0.02 & 390 \\
\hline
\end{tabular}

Molar growth yields and oxidative phosphorylation

For wild-type bacteria growing anaerobically a molar growth yield of 23 was found. Raising the dissolved oxygen concentration in the medium resulted in an increase in the molar growth yield and in specific growth rate. At a dissolved-oxygen concentration of 


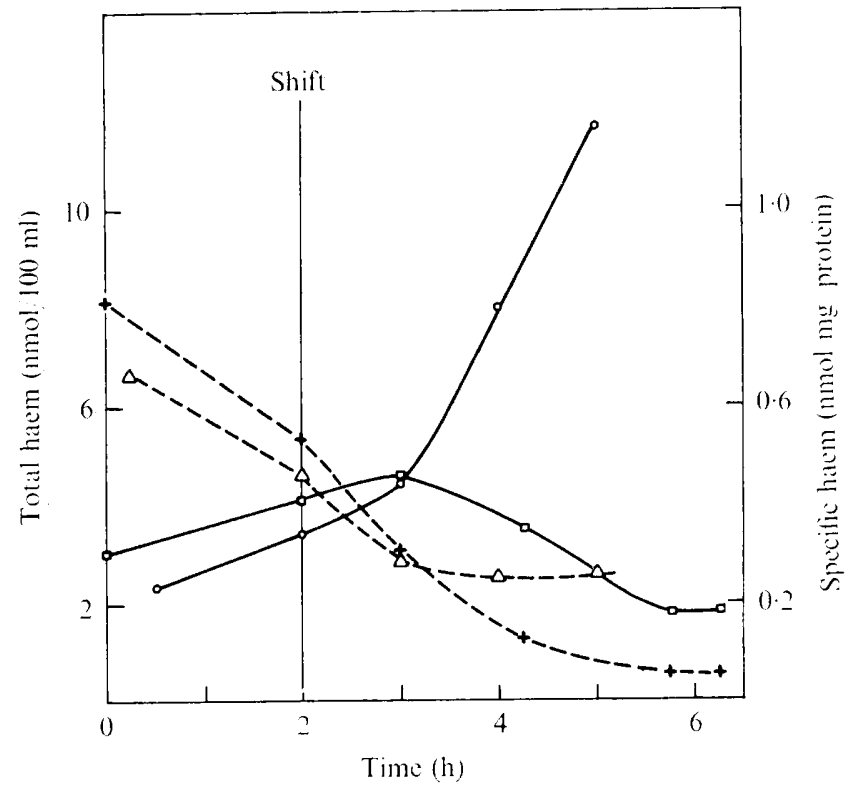

Fig. 4. Intracellular haem in $P$. aeruginosa s 838 wild type and si 276 aer before and after a shift from anaerobic to aerobic conditions. Growth conditions as in Fig. I. Haem concentration is expressed as $\mathrm{nmol} / \mathrm{I} 00 \mathrm{ml}$ culture fluid $(-)$ or as $\mathrm{nmol} / \mathrm{mg}$ cellular protein $(---) .0, \angle, \mathrm{s} 838$; $\square,+, \operatorname{si} 276$.

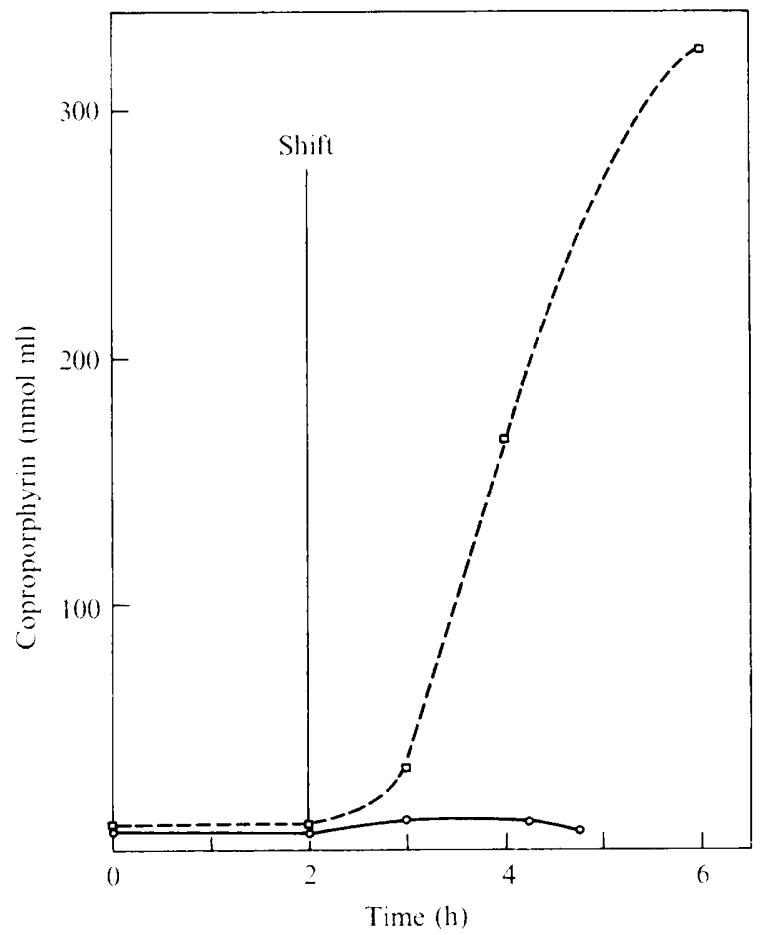

Fig. 5. Concentration of coproporphyrin in the culture fluid of $P$. aeruginosa $\mathrm{s} 838$ wild type and SI 276 aer before and after a shift from anaerobic to aerobic conditions. Growth conditions as in Fig. I. 0, s838; $\square$, s1276. 
$37.5 \mu \mathrm{M}$ and under strict aerobiosis, molar growth yields of 34 and 40 were found respectively. For the aer mutant the anaerobic molar growth yield was also 23 , whereas at $37.5 \mu \mathrm{M}$ dissolved oxygen the value was only 14 . This difference might be explained by assuming that mutant bacteria have a defect in phosphorylation coupled to respiration with oxygen but not to respiration with nitrate, in addition to the defect in aerobic haem synthesis.

For the aer mutant bacteria cultured anaerobically a $\mathrm{P} / \mathrm{O}$ ratio of 0.20 was found. For wild-type bacteria grown anaerobically or aerobically $\mathrm{P} / \mathrm{O}$ ratios of about 0.43 were found, values which agree with those of van der Beek \& Stouthamer (1973). After a shift from anaerobic to aerobic conditions a $\mathrm{P} / \mathrm{O}$ ratio of 0.42 was found for mutant bacteria (Table 2 ). During the $\mathrm{P} / \mathrm{O}$ determinations it was observed that the rates of oxygen uptake and ATP production were about five times lower in mutant bacteria grown to the stationary phase

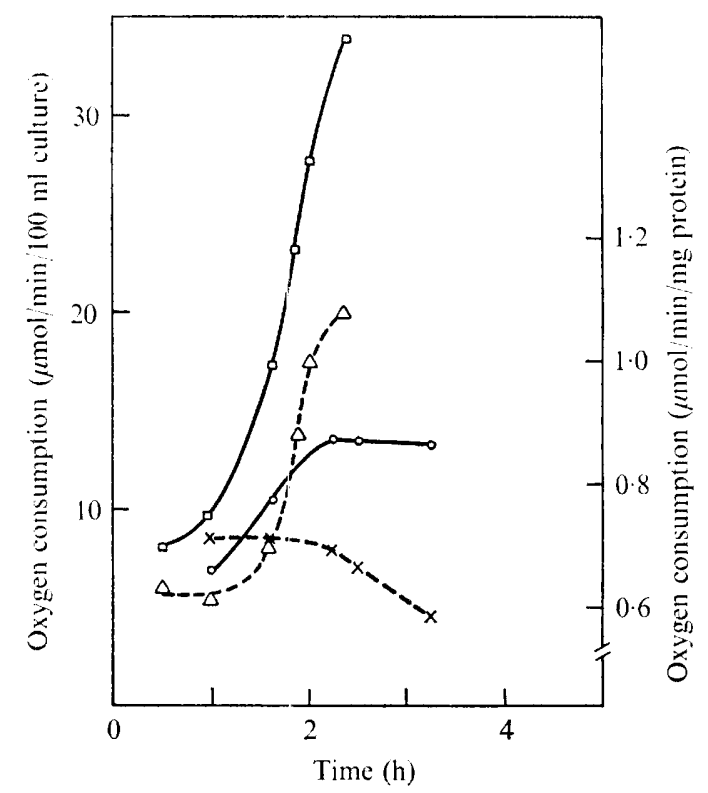

Fig. 6. Total (-) and specific (-- ) oxygen uptake of cultures of $P$. aeruginosa $\mathrm{s} 838$ wild type and S1276 aer after a shift from anaerobic to aerobic conditions. Growth conditions as in Fig. I. Total uptake is expressed as $\mu \mathrm{mol} / \mathrm{min} / \mathrm{I} 00 \mathrm{ml}$ culture; specific uptake as $\mu \mathrm{mol} / \mathrm{min} / \mathrm{mg}$ cellular protein. $\square, \triangle$, s838; $O, \times$, sI 276 .

Table 2. Oxidative phosphorylation, expressed as $P / O$ ratios, in intact stationary-phase bacteria of the wild type and the aer mutant strain of $P$. aeruginosa after different culture conditions

\begin{tabular}{lccc} 
& \multicolumn{3}{c}{ Culture conditions } \\
Strain & Anaerobic & Aerobic & $\begin{array}{c}\text { Aerobic after } \\
\text { a shift }\end{array}$ \\
S838 wild type & 0.40 & 0.46 & N.D. \\
SI 276 aer & 0.20 & N.G. & 0.42
\end{tabular}

N.D., Not determined; N.G., no growth. 
after a shift from anaerobic to aerobic conditions than in wild-type bacteria grown aerobically. This is in agreement with the data of Fig. 6 . The difference between the $\mathrm{P} / \mathrm{O}$ ratios of anaerobically grown wild-type and mutant bacteria has previously been unexplained. However, respiration with oxygen is coupled to ATP formation in the mutant, so we conclude that the low molar growth yield of mutant bacteria grown at a dissolved-oxygen concentration of $37.5 \mu \mathrm{M}$ is due to an inefficient coupling between energy production and biomass formation caused by the shortage of haem under these conditions.

\section{DISCUSSION}

Under aerobic conditions the aer mutant of Pseudomonas aeruginosa did not synthesize haem and released coproporphyrin to the medium. After a shift to aerobiosis, aer mutant bacteria continued to grow, haem and cytochromes were diluted out, and the respiratory activity decreased. Similar mutants have been isolated from Rhodopseudomonas spheroides (Wittenberg \& Sistrom, 1971), Escherichia coli (Cox \& Charles, 1973) and Saccharomyces cerevisiae (Miyake \& Sugimura, I968).

Goldfine \& Bloch (1963) supposed an aerobic and an anaerobic mechanism to form the vinyl side chains of protoporphyrin, analogous to the aerobic and anaerobic mechanisms for synthesis of mono-unsaturated fatty acids. Conversion of coproporphyrin into protoporphyrin both under aerobic and anaerobic conditions of assay was demonstrated for a Pseudomonas species (Ehteshamuddin, I968), Rhodopseudomonas spheroides (Tait, 1969) and Chromatium (Tait, I972). Tait (1972) detected some differences between the systems. Our results with the aer mutant of Pseudomonas aeruginosa agree with the hypothesis of Goldfine \& Bloch ( 1963 ). The anaerobic conversion of coproporphyrin into protoporphyrin is unaffected, but the aerobic conversion is blocked in the mutant. Molecular oxygen must repress, inhibit or inactivate the anaerobic route.

Oxygen repressed and inactivated nitrate and nitrite reductase and inhibited these activities in the wild type of Pseudomonas aeruginosa, as also found by Fewson \& Nicholas (196I). In the mutant, however, nitrate and nitrite reduction and the synthesis of nitrite reductase continued after a shift to aerobic conditions. Probably synthesis of haem compounds is necessary to cause the effects of oxygen on the nitrate respiratory system in the wild type. Both in mutant and wild-type bacteria nitrate reductase is inactivated by oxygen, indicating that haem synthesis is not necessary for this inactivation.

Previously it was considered that the aer mutants were most probably not affected in ATP generation under aerobic conditions (van Hartingsveldt \& Stouthamer, 1973). However, the possibility could not then be excluded that in the aer mutant respiration with oxygen, in contrast to respiration with nitrate, is not coupled to ATP formation. The direct determination of $\mathrm{P} / \mathrm{O}$ ratios in intact bacteria and the ability to grow after a shift in nitrate-free medium exclude this possibility. None the less, from the present results it must be concluded that the defect in aerobic growth in the aer mutant is indeed due to a defect in ATP generation under aerobic conditions, since the block in haem biosynthesis prevents the formation of a functional respiratory chain.

We are grateful to Miss F. A. de Meijere for her technical assistance, to Dr E. G. van der Beek for his advice on the $\mathrm{P} / \mathrm{O}$ determinations, and to Dr W. de Vries for critical reading of the manuscript. 


\section{REFERENCES}

Van der Beek, E. G. \& Stouthamer, A. H. (1973). Oxidative phosphorylation in intact bacteria. Archiv fïr Mikrobiologie 89, 327-339.

Cato, E. P., Cummins, C. S., Holdeman, L. V., Johnson, J. L., Moore, W. E. C., Smibert, R. M. \& SмrTH, L. D. S. (1970). Outline of Clinical Methods in Anaerobic Bacteriology. Blacksburg, Virginia: Virginia Polytechnic Institute and State University.

Cox, R. \& Charles, H. P. (1973). Porphyrin-accumulating mutants of Escherichia coli. Journal of Bacterio$\log y \mathrm{II3}, 122-132$.

EHTESHAMUDDIN, A. F. M. (1968). Anaerobic formation of protoporphyrin IX from coproporphyrinogen III by bacterial preparations. Biochemical Journal 1o7, 446-447.

FalK, J. E. (1964). Porphyrins and metalloporphyrins. Amsterdam: American Elsevier Publishing.

Fewson, C. A. \& Nicholas, D. J. D. (1961). Nitrate reductase from Pseudomonas aeruginosa. Biochimica et biophysica acta 49,335-349.

Goldfine, H. \& Bloch, K. (1963). Oxygen and biosynthetic reactions. In Control Mechanisms in Respiration and Fermentation, pp. 8I-I03. Edited by B. Wright. New York: Ronald Press.

van Hartingsveldt, J., Marinus, M. G. \& Stouthamer, A. H. (I97 I). Mutants of Pseudomonas aeruginosa blocked in nitrate or nitrite dissimilation. Genetics 67, 469-482.

van Hartingsveldt, J. \& Stouthamer, A. H. (1973). Mapping and characterization of mutants of Pseudomonas aeruginosa affected in nitrate respiration in aerobic or anaerobic growth. Journal of General Microbiology 74, 97-106.

Lowry, O. H., Rosebrough, N. J., Farr, A. L. \& Randall, R. J. (1951). Protein measurement with the Folin phenol reagent. Journal of Biological Chemistry 193, 265-275.

MACKeCHNIE, I. \& DAWES, E. A. (1969). An evaluation of the pathways of metabolism of glucose, gluconate and 2-oxogluconate by Pseudomonas aeruginosa by measurement of molar growth yields. Journal of General Microbiology 55, 34I-349.

Miyake, S. \& Sugimura, T. (1968). Coproporphyrinogenase in a respiration-deficient mutant of yeast lacking all cytochromes and accumulating coproporphyrin. Journal of Bacteriology 96, 1977-2003.

Pichinoty, F., Bigliardi-Rouvier, J. \& Rimassa, R. (I969). La dénitrification bactérienne. I. Utilisation des amines aromatique comme donneuses d'électrons dans la réduction du nitrite. Archiv für Mikrobiologie 69, 3 I 4-329.

van 'T Riet, J., Stouthamer, A. H. \& Planta, R. J. (1968). Regulation of nitrate assimilation and nitrate respiration in Aerobacter aerogenes. Journai of Bacteriology 96, I455-I464.

TAIT, G. H. (1969). Coproporphyrinogenase activity in extracts from Rhodopseudomonas spheroides. Biochemical and Biophysical Research Communications 37, I 16-1 22.

TAIT, G. H. (1972). Coproporphyrinogenase activities in extracts of Rhodopseudomonas spheroides and Chromatium strain D. Biochemical Journal 128, I 59-1 169.

DE VRIes, W. \& Stouthamer, A. H. (1968). Fermentation of glucose, lactose, galactose, mannitol and xylose by bifidobacteria. Journal of Bacteriology 96, 472-478.

de Vries, W., van Wijck-Kapteijn, W. M. C. \& Stouthamer, A. H. (1972). Influence of oxygen on growth, cytochrome synthesis and fermentation pattern in propionic acid bacteria. Journal of General Microbiology 71, 515-524.

WitTENBERG, T. \& Sistrom, W. R. (1971). Mutant of Rhodopseudomonas spheroides unable to grow aerobically. Journal of Bacteriology 106, 732-738.

Yamanaka, T., OTA, A. \& OKUnUKI, K. (196I). A nitrite reducing system reconstructed with purified cytochrome components of Pseudomonas aeruginosa. Biochimica et biophysica acta 53, 294-308. 